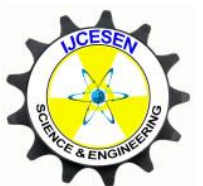

Copyright (C) IJCESEN
International Journal of Computational and

Experimental $\boldsymbol{S}$ cience and $\boldsymbol{E N g i n e e r i n g}$

(IJCESEN)

Vol.5 -No.1 (2019) pp. 48-51

http://dergipark.gov.tr/ijcesen

Research Article

\title{
Natural Radiation Measurement in Some Soil Samples from Basra oil field, IRAQ State
}

\author{
Hadi AL-BAIDHANI ${ }^{1}$, Kadir GUNOGLU ${ }^{2}$ and Iskender AKKURT ${ }^{1}$ \\ 1 Suleyman Demirel University/Department of physics, Isparta, TURKEY \\ 2 Suleyman Demirel University /Technical Vocational School, Isparta, TURKEY \\ * Corresponding Author : hadi_albadany@yahoo.com \\ ORCID: 0000-0001-9230-1510
}

\section{$\underline{\text { Article Info: }}$}

DOI: $10.22399 /$ ijcesen.498695

Received : 30 December 2018

Accepted : 01 March 2019

\section{Keywords}

Radiation

Soil

Uranium

Thorium

\begin{abstract}
$\underline{\text { Abstract: }}$
The main objective of this project is to study the natural radioactivity in the oil field environment, and its potential future effects on the workers in particular and the environment in general when increasing the concentration of natural radionuclides resulting from oil extraction. This is done by collecting a number of soil samples, were taken from one of the oil fields north of the Basra city, and the measurement was performed using a gamma ray spectrometry that contains a 3"x3" NaI(Tl) detector at gamma spectrometry laboratory of Süleyman Demirel University,Isparta-Turkey. The normal radioactivity of radionuclides for natural isotopes ${ }^{238} \mathrm{U},{ }^{232} \mathrm{Th}$ and ${ }^{40} \mathrm{~K}$ are evaluated after measuring by comparing results with worldwide average values in natural soil. The average values of the measurement results were within the worldwide average values, and there were increase Radioactivity concentrations of Radium and potassium in sample 3, that required monitoring to this site for any increase in radioactivity, also to taking of the preventive measures.
\end{abstract}

\section{Introduction}

The exposure of Radiation is varying in the environment; some of them come from industrial sources as Medical exposure sources (X-ray), or from natural sources which are found around us, such as cosmic rays and terrestrial radiation [1].

The natural terrestrial radioactivity is present resulting of radionuclides already present in the earth's crust with different concentrations in nature, which does not pose a risk to the environment unless there are human processes and activities that lead to an increase in the concentration of radionuclides and concentration of activity which leads to exposure to radiation risk, as a Mineral exploration, coal mine drilling, and oil and gas extraction [2].

The natural radionuclides found in geological deposits are occurring from decay to the natural elements with a long half-life, such as uranium-238, thorium-232, and potassium-40. The produce radionuclides by this decay are transferred through the pores of the rocks to the oil formations places, they brought to the surface by produced water that accompanying with oil extracted in the form of soluble salts such as Radium-226 salts, The changes of some physical factors such as pressure or temperature etc. leads to accumulation of sediments Inside the oil equipment in different forms, containing radionuclides that are more concentrated by increasing the accumulation of those sediments which lead to the reduction of oil production over time, which requires to cleaning of the equipment periodically and continuously, which leads exposure of radiation risk to the workers and pollution of land surrounding the oil fields and the environment if they are not handled safely and uncontrolled to prevent their spread [3].

In the literature, some researchers have carried out a series of studies to identify and evaluate ${ }^{226} \mathrm{Ra}$, ${ }^{232} \mathrm{Th}$ and ${ }^{40} \mathrm{~K}$ activity concentrations in environmental samples such as stone, soil in various parts of the world [4-16]. 
In this study, ${ }^{226} \mathrm{Ra},{ }^{232} \mathrm{Th}$ and ${ }^{40} \mathrm{~K}$ activity concentrations of 4 soil samples that collected from one of the oil fields north of the Basra city were measured.

\section{Materials and Methods}

\subsection{Area of Study}

Basra oil fields, a group of oil wells discovered, which is actually investment of oil and extends from the middle of the west of Basra to the north of Kuwait, includes a vast area of $1,600 \mathrm{Km}^{2}$. Basra fields are divided into two parts the Northern Basra and the Southern Basra close to Kuwait, see Figure 1. The type of oil extracted in this field from sandstone layers, at depths of up to four kilometres, Sand formations are characterized by their high quality, which has an average porosity of $20 \%$ in addition to high permeability.

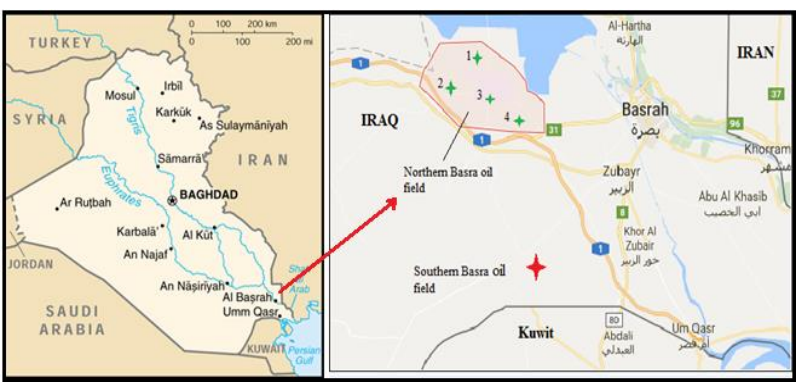

Figure 1. Samples location of Basra oil fields on Iraq map

\subsection{Sample Collection and Preparation}

Randomly four soil samples from the area shown in the Figure 1 were taken from the surfaces near to the different oil equipment at Northern Basra oil field. All samples were dried to remove moisture using an oven at $100{ }^{\circ} \mathrm{C}$ for 12 hours; About $200 \mathrm{~g}$ for each sample was taken after removal of stones and biological parts by using a $1 \mathrm{~mm}$ sieve and then filled in a special plastic counting container. The containers were stored for one month before counting its radioactivity allowing for achieving the equilibrium between isotopes of ${ }^{226} \mathrm{Ra},{ }^{228} \mathrm{Ra}$, and decay of its products.

\subsection{Radioactivity Measurement}

The natural radioactivity of the radionuclides that emit gamma-ray can be measured based on the high penetration strength of the gamma-rays in materials, using electronic counting and analysis system used in the detection of nuclear radiation, from the sodium iodide detector with thallium $\mathrm{NaI}(\mathrm{Tl})$ that have dimension $(3 " \times 3 ")$ which was connected with high voltage (HV), preamplifier and multichannel analyser, (ORTEC-Digit Base) which contains 16384 channel, connects In a unit called ADC (Analog to Digital Converter) Helps the analyst to convert the coming pulse into digital form, Radiation measurements and analysis are done by computer software called (MAESTRO-32) to record data, as illustrated in figure. 2



Figure 2. Schematic of gamma-ray spectrometer system

The radioactivity measurement of the samples was done after measuring the background radiation; by subtracting the value of radiation background from the value of radioactivity of the measured sample we obtain the net of the radioactivity, in the same time period as the sample measurement (84000) sec. The qualitative analysis is depending on determining the gamma-ray energy emitted from the measured sample, and recording of quantities for the natural radioactivity of isotopes ${ }^{226} \mathrm{Ra},{ }^{232} \mathrm{Th}$, and ${ }^{40} \mathrm{~K}$ which are counted its energies from the photo peak which equal to 1760,2610 , and 1461 $\mathrm{keV}$, respectively [4], as illustrated in figure. 3

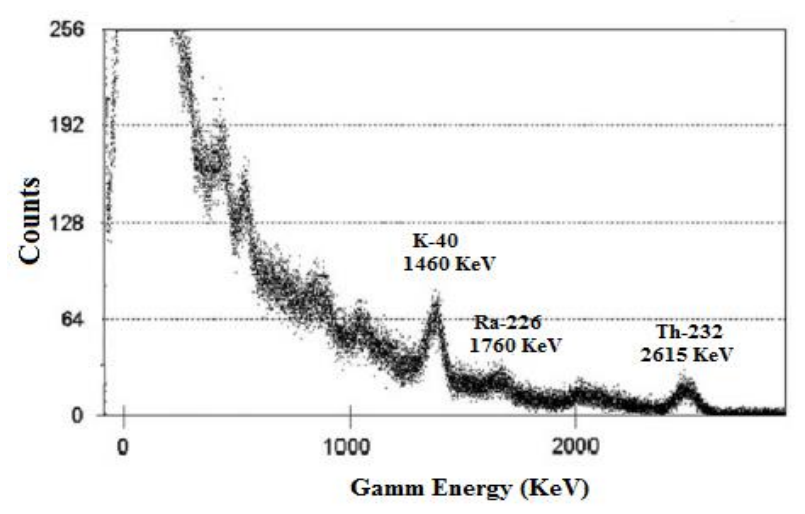

Figure 3. A spectrum measurement for natural radioactivity

In the quantitative analysis, the radioactivity was calculated by calculating the net area under the photo peak of gamma-ray to infer the concentration of radioisotope in the sample. The activities for the natural radionuclides of ${ }^{40} \mathrm{~K},{ }^{226} \mathrm{Ra}$ and ${ }^{232} \mathrm{Th}$ in the measured samples at Becquerel per unit mass $\mathrm{Bq} / \mathrm{kg}$ were calculated using the following relation [4].

$$
A=\frac{N_{\text {net }}}{\varepsilon \cdot \gamma \cdot t \cdot m}
$$

where $\mathrm{A}$ is the radioactivity of measured radionuclides in $\mathrm{Bq} / \mathrm{kg}, N_{\text {net }}$ is the net count rate 
area under the photopeaks calculated from (Total counts - background counts), $\varepsilon$ is the efficiency of detector to emitted gamma rays, $\gamma$ is the relative intensity of all gamma energy emitted, $t$ is the time of counting and $m$ is a mass of sample in $(\mathrm{kg})$.

\section{Results and Discussion}

The activity concentration of the radionuclides for the 4 soil samples from North Basra oil field were obtained using the relation 1 and given in Table 1 .

Table 1. The radioactivity concentration in soil samples

\begin{tabular}{|c|c|c|c|}
\hline $\begin{array}{c}\text { Sample } \\
\mathbf{I d}\end{array}$ & $\begin{array}{c}{ }^{40} \mathbf{K} \\
(\mathbf{B q} / \mathbf{K g})\end{array}$ & $\begin{array}{c}{ }^{226} \mathbf{R a} \\
(\mathbf{B q} / \mathbf{K g})\end{array}$ & $\begin{array}{c}{ }^{232} \mathbf{T h} \\
(\mathbf{B q} / \mathbf{K g})\end{array}$ \\
\hline 1 & 430.3475 & 18.562 & 19.1908 \\
\hline 2 & 403.1239 & 27.961 & 22.2103 \\
\hline 3 & 684.3209 & 62.533 & 25.8814 \\
\hline 4 & 528.624 & 25.297 & 15.3056 \\
\hline Average & 511.604 & 33.588 & 20.647 \\
\hline
\end{tabular}

In this table, it can be seen the activity variation for these samples. The radioactivity of natural radionuclides is evaluated after measuring by comparing results with worldwide average values in natural soil. The worldwide average value of ${ }^{40} \mathrm{~K}$, ${ }^{226} \mathrm{Ra}$, and ${ }^{232} \mathrm{Th}$ in the normal soil is 400,35 , and $30 \mathrm{~Bq} / \mathrm{kg}$, respectively $[17,18]$. It can be seen that activity concentration of ${ }^{40} \mathrm{~K}$ for all samples are more than the worldwide average value and activity concentration of ${ }^{226} \mathrm{Ra}$ for sample 3 more than the worldwide average value. While the activity concentration value of the other samples was lower, these results are displayed in Figure 4 and Figure 5. In Table-2, the activity concentrations of the ${ }^{40} \mathrm{~K}$, ${ }^{232} \mathrm{Th}$ and ${ }^{226} \mathrm{Ra}$ radionuclides obtained in this study were compared with similar studies in different countries and with recommended limit values.

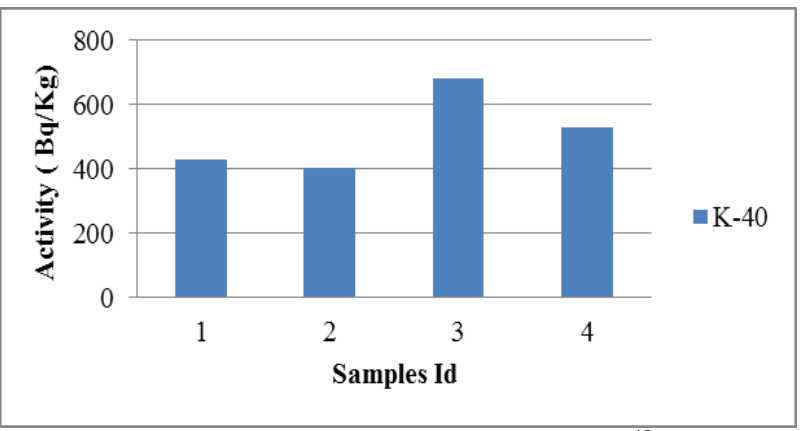

Figure 4. Activity concentrations of ${ }^{40} \mathrm{~K}$

\section{Conclusion}

The average activity results obtained from the

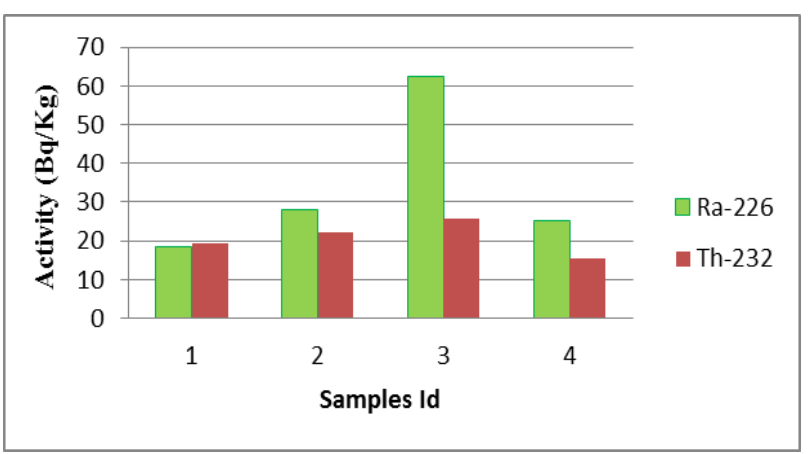

Figure 5. Activity concentrations of ${ }^{226}$ Ra and ${ }^{232} \mathrm{Th}$

Table 2. A comparison of radioactivity content from other parts of the world.

\begin{tabular}{|l|c|c|c|c|}
\hline \multirow{2}{*}{\multicolumn{1}{|c|}{ Location }} & \multicolumn{3}{|c|}{$\begin{array}{c}\text { Activity concentration } \\
\text { (Bq/kg) }\end{array}$} & \multirow{2}{*}{ References } \\
\cline { 2 - 4 } & ${ }^{\mathbf{4}} \mathbf{K}$ & ${ }^{\mathbf{2 2 6}} \mathbf{R a}$ & ${ }^{\mathbf{2 3 2}} \mathbf{T h}$ & \\
\hline Egypt & 21,1 & 930 & 11,6 & {$[19]$} \\
\hline Saudi Arabia & 641,08 & 11,42 & 19,26 & {$[20]$} \\
\hline Thailand & 523 & 22,6 & 26,4 & {$[21]$} \\
\hline Malaysia & 369 & 31 & 36 & {$[22]$} \\
\hline Palestine & 113 & 41 & 19 & {$[23]$} \\
\hline Pakistan & 575 & 31 & 44 & {$[24]$} \\
\hline Nigeria & 710 & 25 & 77 & {$[25]$} \\
\hline Turkey & 12,2 & 157,7 & 9 & {$[26]$} \\
\hline Saudi Arabia & 153,8 & 11,3 & 6,7 & {$[27]$} \\
\hline World (average) & 400 & 35 & 30 & {$[17]$} \\
\hline Iraq & 511,6 & 33,59 & 20,65 & This Work \\
\hline
\end{tabular}

measurements are consistent with the activity values given in the UNSCEAR 2000 reports for all samples except for the ${ }^{40} \mathrm{~K}$ activity values. Therefore, these activity concentrations are acceptable levels for human health or environmental pollution.

\section{Acknowledgement}

The Authors would like to thanks to Iraq Ministry of oil and Suleyman Demirel University,Turkey for supporting these research activities.

\section{References}

[1] Australian Radiation Protection and Nuclear Safety Agency (ARPANSA). Management of Naturally Occurring Radioactive Material (NORM) No. 15. (2008).

[2] Khadhim, N. F., \& Adnan, O. H, 2016. Measurement of natural radioactivity in Al-Dora Refinery by using (HPGe) detector. 
[3] AL-MASRI, M. S., SUMAN, H., NORM waste in the oil and gas industry: the Syrian experience, J. Radioanal. Nucl. Chem. 256, (2003), 159-162.

[4] Akkurt I. and Gunoglu,K., 2014. Natural Radioactivity Measurements and Radiation Dose Estimation in Some Sedimentary Rock Samples in Turkey. Science and Technology of Nuclear Installations Volume 2014, Article ID 950978

[5] Akkurt, I., Oruncak, B., Gunoglu,K., 2010. Natural radioactivity and dose rates in commerciallyused marble from Afyonkarahisar - Turkey. International Journal of the Physical Sciences Vol. 5 (2), p:170-173.

[6] Günay O., 2018 , Determination of Natural Radioactivity and Radiological Effects in some Soil Samples in Beykoz-Istanbul, European Journal of Science and Technology No. 12, pp. 9-14, April 2018 ISSN:2148-2683

[7] Carvalho, C., Anjos, R.M., Veiga, R., Macario, K., 2011. Application of radiometric analysis in the study of provenance and transport processes of Brazilian coastal sediments. J. Environ. Radioact. 102 , 185-192. https://doi.org/10.1016/j.jenvrad.2010.11.011

[8] İskender AKKURT, N. Ayten UYANIK, Kadir GÜNOĞLU "Radiation dose Estimation: An in vitro Measurement for Isparta-Turkey" IJCESEN 1-1(2015)1-4 DOI: 10.22399/ijcesen.194376

[9] Carvalho, C., Anjos, R.M., Veiga, R., Macario, K., 2011. Application of radiometric analysis in the study of provenance and transport processes of Brazilian coastal sediments. J. Environ. Radioact. 102 ,

185-192. https://doi.org/10.1016/j.jenvrad.2010.11.011

[10] Günay, O. (2018). Assessment of lifetime cancer risk from natural radioactivity levels in Kadikoy and Uskudar District of Istanbul. Arabian Journal of Geosciences, 11(24), 782.

[11] Ramasamy, V., Sundarrajan, M., Paramasivam, K., Suresh, G., 2015. Spatial and depth wise characterization of radionuclides and minerals in various beach sediments from high background radiation area, Kerala, India. Appl. Radiat. Isot. 95, 159-168.

[12] Seçkiner S., Akkurt, I., Günoglu K., 2017, Determination of $40 \mathrm{~K}$ concentration in gravel samples from Konyaaltı Beach, Antalya. Acta Phys. Pol. A., Vol 132 (3-II), 1095-1097,doi: 10.12693/APhysPolA.132.1095.

[13] I Akkurt, B Oruncak, K Gunoglu 2010, Natural radioactivity and dose rates in commercially-used marble from Afyonkarahisar-TurkeyInternational Journal of Physical Sciences 5 (2), 170-173

[14] NA Uyanık, O Uyanık, İ Akkurt 2013, Microzoning of the natural radioactivity levels and seismic velocities of potential residential areas in volcanic fields: The case of Isparta (Turkey) Journal of Applied Geophysics 98, 191-204

[15] B Çetin, F Öner, I Akkurt 2016, Determination of natural radioactivity and associated radiological hazard in excavation field in Turkey (Oluz Höyük) Acta Physica Polonica A 130 (1), 475-478
[16] NA Uyanik, I Akkurt, O Uyanik 2011, A ground radiometric study of uranium, thorium and potassium in Isparta, Turkey Annals of Geophysics 53 (5-6), 25-30

[17] UNSCEAR, 2000. Sources and effects of ionizing radiation. United Nations Scientific Committee on the effect of atomic radiation. Report to the General Assembly, with Scientific Annexes. United Nations, New York.

[18] N. Zaim, A.B. Tugrul, H. Atlas, B. Buyuk, E. Demir. Investigation of Natural Radioactivity of Surface Soil Samples in the Vicinity of Edirne Turkey, Acta Physica Polonica A, page 64 (2016), DOI: 10.12693/APhysPolA.130.64.

[19] Harb, S., 2008. Natural radioactivity and external gamma radiation exposure at the coastal Red Sea in Egypt. Radiat. Prot. Dosimetry 130 (3), 376-384.

[20] Al-Trabulsy, H., Khater, A., Habbani, F., 2011. Radioactivity levels and radiological hazard indices at the Saudi coastline of the Gulf of Aqaba. Radiat. Phys. Chem. 80, 343-348.

[21] Malain, D., Regan, P.H., Bradley, D.A., Matthews, M., Al-Sulaiti, H.A., Santawamaitre, T., 2012. An evaluation of the natural radioactivity in Andaman beach sand samples of Thailand after the 2004 tsunami. Appl. Radiat. Isot. 70 (8), 1467-1474.

[22] Almayahi, B.A., Tajuddin, A.A., Jaafar,M.S., 2012. Effect of the natural radioactivity concentrations and 226Ra/238U disequilibriumon cancer diseases in Penang,Malaysia. Radiat. Phys. Chem. 81, 1547-1558.

[23] Abu Samreh MM, Thabayneh KM, Khrais FW (2014) Measurement of activity concentration levels of radionuclides in soil samples collect- ed from Bethlehem Province, West Bank, Palestine. Turk J Eng Environ Sci 38:113-125.

[24] Rafique M, Ur Rahman S, Basharat M, Aziz W, Ahmad I, Lone KA, Ahmad K, Matiullah M (2014) Evaluation of excess life time cancer risk from gamma dose rates in Jhelum valley. Journal of Radiation Research and Applied Sciences 7:29-35.

[25] Oyeyemi KD, Usikalu MR, Aizebeokhai AP, Achuka JA, Jonathan O (2017) Measurements of radioactivity levels in part of Ota Southwestern Nigeria: Implications for radiological hazards indices and excess life- time cancer-risks IOP. Conf. Series: Journal of Physics: Conf. Series 852:1-8.

[26] Özmen, S.F., Cesur, A., Boztosun, I., Yavuz, M., 2014. Distribution of natural and anthropogenic radionuclides in beach sand samples from Mediterranean Coast of Turkey. Radiat. Phys. Chem. 103, 37-44.

[27] Al-Ghamdi, H., Al-Muqrin, A., El-Sharkawy, A., 2016. Assessment of natural radioactivity and 137 Cs in some coastal areas of the Saudi Arabian gulf. Mar. Pollut. Bull. 104, 29-33. 